\title{
Sodium Ameliorates the Effect of Potassium Deficiency in Cauliflower Leaves
}

\author{
C.P. Sharma and Sandhya Singh \\ Department of Botany, Lucknow University, Lucknow-226 007, India
}

Additional index words. Brassica oleracea (Botrytis Group), reducing sugar, nonreducing sugar, starch, nonprotein nitrogen, protein nitrogen

\begin{abstract}
Cauliflower [Brassica oleracea (Botrytis Group) cv. Pusi] grown in refined sand with 0.01 normal $K$ supply had lower dry matter and tissue concentration of $K$ than the controls and developed visible symptoms characteristic of $\mathrm{K}$ deficiency. Compared with control plants, the laminae of K-deficient plants contained significantly higher concentrations of sugars and nonprotein $N$ and significantly lower concentrations of starch and protein N. However, the midribs of K-deficient leaves contained more protein $N$ than leaves of control plants. Substitution of $K$ by $\mathrm{Na}$ resulted in increased $\mathrm{Na}$ concentrations in leaves and recovery from the K-deficiency effect on the carbohydrate and $\mathbf{N}$ fractions. Maximum response to sodium was found in the intercoastal-lamina of $\mathrm{K}$-deficient plants.
\end{abstract}

In an earlier paper (Sharma and Singh, 1990), we demonstrated that the negative effect of $\mathrm{K}$ deficiency on water relations of cauliflower was overcome by $\mathrm{Na}$. Inadequate $\mathrm{K}$ supply in plants is also known to inhibit the synthesis of highly polymerized compounds, such as starch and protein, leading to corresponding increases in low molecular weight sugars and amino acids (Basha et al., 1980; Mengel and Helal, 1968; Nowakowski, 1971; Okamato, 1967; Ratner and Yeliseova, 1968). The objective of this work was to determine whether $\mathrm{Na}$ can overcome the K-deficiency effect on carbohydrate and nitrogenous compounds in cauliflower and how the distribution of carbohydrate and $\mathrm{N}$ fractions in leaves is modified if low $\mathrm{K}$ is compensated by Na.

Cauliflower plants were grown in refined sand (Hewitt, 1966) in 8-liter white plastic pots. Plants were separated into three groups 30 days after sowing. The control (normal
K) was $4 \mathrm{~mm} \mathrm{~K}$ supplied as sulfate. The other two groups (low K) were supplied 0.4 $\mathrm{mM} \mathrm{K}$, with one group receiving $3.6 \mathrm{mM}$ as sodium sulfate in addition to the $0.4 \mathrm{~mm} \mathrm{~K}$. Treatments were arranged in a completely random design with three replications and eight plants per pot. Nitrogen was supplied as a combination of $4 \mathrm{~mm}$ nitrate and $2 \mathrm{~mm}$ ammonium. The composition of basal nutrient solution was (in mM): $4 \mathrm{Ca}\left(\mathrm{NO}_{3}\right)_{2}, 2$ $\mathrm{MgSO}_{4}, 1.33\left(\mathrm{NH}_{4}\right)_{2} \mathrm{HPO}_{4}, 0.1 \mathrm{NaCl}, 0.1$ Fe-EDTA; (in $\mu \mathrm{M}$ ): $10 \mathrm{MnSO}_{4}, 1 \mathrm{CuSO}_{4}, 1$ $\mathrm{ZnSO}_{4}, 33 \mathrm{H}_{3} \mathrm{BO}_{3}, 0.2 \mathrm{Na}_{2} \mathrm{MoO}_{4}, 0.1 \mathrm{CoSO}_{4}$, and $0.1 \mathrm{NiSO}_{4}$. Plants were maintained under glasshouse conditions for 123 days be$4.0 \mathrm{~K}^{+}, 0.4 \mathrm{~K}^{+}$, or $0.4 \mathrm{~K}^{+}+3.60 \mathrm{Na}^{+}$. tween October and February.

After 7.5 days of growth, when plants showed moderate $\mathrm{K}$ deficiency, they were harvested for determination of dry matter, which was measured after drying the fresh plant material in a forced-draft oven maintained at $70 \mathrm{C}$ for $48 \mathrm{~h}$. Additional plants were harvested to obtain leaves of a similar physiological age as those used for dry-matter determination (sixth or seventh from the top). Laminae of these leaves were separated into midrib, intercoastal, and marginal sections. The three sections were measured for tissue concentration of $\mathrm{K}, \mathrm{Na}$, sugars, starch, and $\mathrm{N}$.

Potassium and $\mathrm{Na}$ were determined by flame photometry after digestion of the ovendried material in a mixture of 10 nitric acid : 1 perchloric acid (Piper, 1942). For the estimations of sugars, starch, protein, and nonprotein $\mathrm{N}$, leaves were chopped and fixed in boiling $80 \%$ ethanol and then macerated in a top-drive homogenizer. The proportion of fresh material to ethanol was 1:10. Ethanol soluble and insoluble fractions were separated by centrifugation at $5000 \times g$ for 10 $\mathrm{min}$. Aliquots were drawn for the determination of sugars and nonprotein $\mathrm{N}$ from the ethanol soluble fraction. Protein $\mathrm{N}$ and starch were determined in ethanol-insoluble material. For estimating sugars, ethanol was removed from the ethanol-soluble fraction by adding $\approx 5 \mathrm{ml}$ distilled water and boiling the mixture in a water bath. The pigments in the extract were removed by treatment with neutral lead acetate. Lead acetate was removed by precipitating with potassium oxalate and filtering. The filterate was made to volume, and the concentration of reducing sugars was measured according to Nelson (1944). Total

Table 1. Dry matter and tissue concentration of $\mathrm{K}$ and $\mathrm{Na}$ in leaves of cauliflower supplied with (mM)

\begin{tabular}{|c|c|c|c|c|c|c|c|}
\hline \multirow{2}{*}{$\begin{array}{l}\mathrm{K} \text { and } \mathrm{Na} \\
\text { supply } \\
\text { (mM) }\end{array}$} & \multirow[b]{2}{*}{$\begin{array}{l}\text { Dry matter } \\
\text { (g/plant) }\end{array}$} & \multicolumn{3}{|c|}{$\begin{array}{c}\text { Potassium } \\
\text { (mmol/g dry wt) }\end{array}$} & \multicolumn{3}{|c|}{$\begin{array}{c}\text { Sodium } \\
\text { (mmol/g dry wt) }\end{array}$} \\
\hline & & $\begin{array}{c}\text { Leaf } \\
\text { margin }\end{array}$ & $\begin{array}{c}\text { Intercoastal } \\
\text { lamina }\end{array}$ & Midrib & $\begin{array}{l}\text { Leaf } \\
\text { margin }\end{array}$ & $\begin{array}{l}\text { Intercoastal } \\
\text { lamina }\end{array}$ & Midrib \\
\hline $4.00 \mathrm{~K}^{+}$ & $4.40 \mathrm{a}$ & $0.346 \mathrm{a}$ & $0.358 \mathrm{a}$ & $0.837 \mathrm{a}$ & $0.629 \mathrm{~b}$ & $0.429 \mathrm{~b}$ & $0.545 b$ \\
\hline $\begin{array}{l}0.40 \mathrm{~K}^{+} \\
0.40 \mathrm{~K}^{+}+\end{array}$ & $2.81 \mathrm{~b}$ & $0.060 \mathrm{~b}$ & $0.085 \mathrm{c}$ & $0.079 \mathrm{~b}$ & $0.032 \mathrm{c}$ & $0.045 \mathrm{c}$ & $0.246 \mathrm{c}$ \\
\hline $3.60 \mathrm{Na}^{+}$ & $3.24 \mathrm{~b}$ & $0.083 \mathrm{~b}$ & $0.122 b$ & $0.081 \mathrm{~b}$ & $1.814 \mathrm{a}$ & $0.554 \mathrm{a}$ & $1.384 \mathrm{a}$ \\
\hline
\end{tabular}

${ }^{\mathrm{z}}$ Mean separation within columns by Duncan's multiple range test, $P=0.05$. Data arc means of three replicates. 
Table 2. Concentrations of sugars, starch, and nitrogen (percent fresh weight) in leaves of cauliflower supplied with $(\mathrm{mM}) 4.0 \mathrm{~K}, 0.4 \mathrm{~K}^{+}$, or $0.4 \mathrm{~K}^{+}+\mathrm{Na}^{+}$.

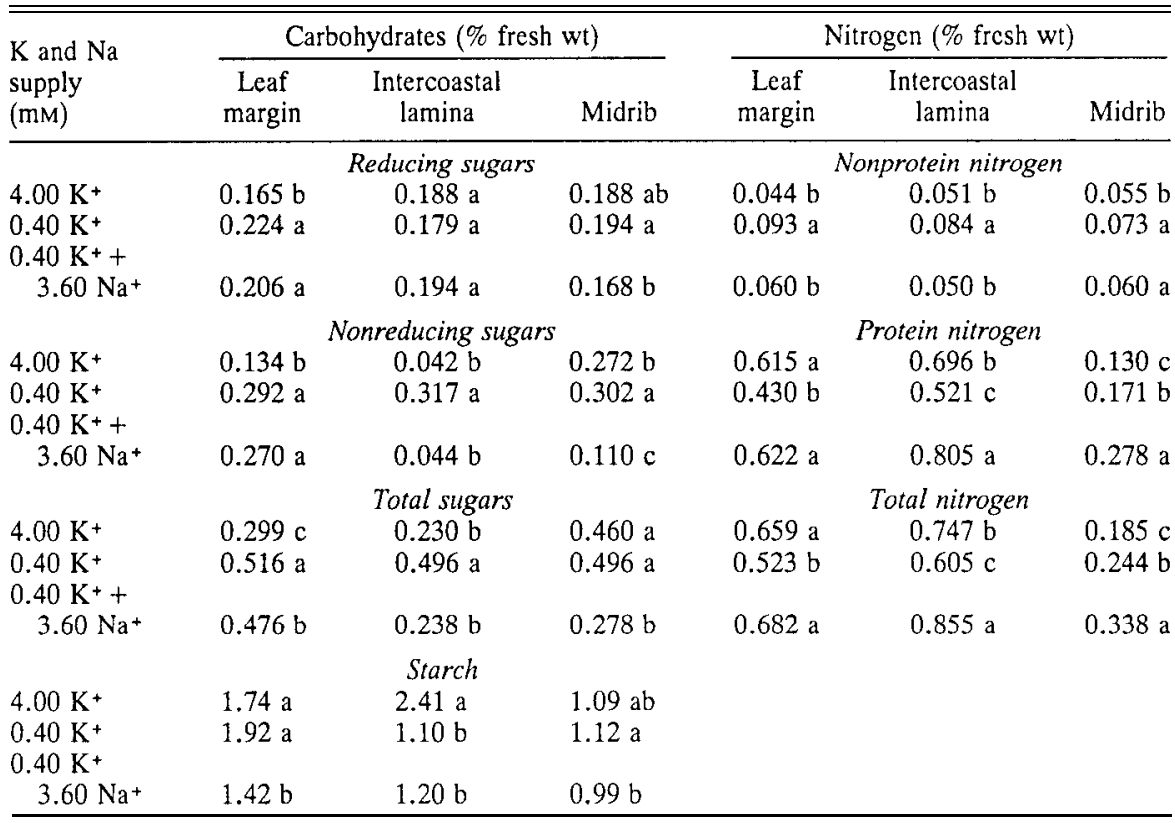

${ }^{\mathrm{z}}$ Mean separation within columns by Duncan's multiple range test, $P=0.05$. Data are means of three replicates

sugars were estimated in the solution after the hydrolysis of nonreducing sugars by invertase. Nonreducing sugars were found by the difference between total and reducing sugars. Starch was estimated in the ethanolinsoluble material by the method of MontGomery (1957). Protein and nonprotein N were estimated by the semi-micro-Kjeldahl method after digesting the samples by the method of Chibnall et al. (1943). The total of protein and nonprotein $\mathrm{N}$ is expressed as total N.

Data were subjected to analysis of variance and mean separation by Duncan's multiple range test.

As reported earlier (Sharma and Singh, 1990), cauliflower plants grown at low K showed retarded growth, with leaves exhibiting undulated lamina and marginal chlorosis. Addition of $\mathrm{Na}$ to low-K plants reduced the severity of visible symptoms of $\mathrm{K}$ deficiency but had no significant effect on dry matter content of plants (Table 1). Leaf tissue concentrations of $\mathrm{K}$ in low-K plants were significantly less than in normal-K plants (Table 1). The addition of Na to low-K plants made no significant change in the tissue concentration of $\mathrm{K}$ in marginal and midrib portions of leaves but caused a significant increase in the concentration of $\mathrm{K}$ in the intercoastal lamina. However, the concentration of $\mathrm{K}$ in the intercoastal lamina of plants supplied additional $\mathrm{Na}$ still remained significantly lower than in normal plants. Deficiency of K caused a significant decrease in $\mathrm{Na}$ concentration in all three parts of the leaves, more so in the marginal and intercoastal lamina than in the midrib. The decrease in Na concentration in low-K plants is at variance with our earlier observations (Sharma and Singh, 1990) and can be attributed to the effect of plant age on $\mathrm{Na}$ accumulation. We observed that 57 days after planting, low-K plants showed higher concentration of $\mathrm{Na}$ than normal-K plants. However, in this study plants were harvested 7.5 days after sowing, and the normal-K, but not low-K, plants showed high accumulation of Na. When K-deficient plants were supplied $\mathrm{Na}$ to the extent $\mathrm{K}$ was deficient, the $\mathrm{Na}$ concentration showed an increase that was not only significantly higher than in leaves of K-deficient plants but also higher than in leaves of normal plants.

Potassium deficiency caused a marked and significant increase in reducing, nonreducing, and total sugars in the marginal parts of leaves (Table 2). Additional Na did not cause any significant change in reducing and nonreducing sugars in the marginal parts of leaves. However, the increase in total sugars in marginal portions of leaves due to $\mathrm{K}$ deficiency was minimized as a result of additional Na supply. Low K supply also resulted in a significant increase in nonreducing and total sugars in the intercoastal lamina. Low $\mathrm{K}$ supply or additional $\mathrm{Na}$ supply did not sugars in the intercoastal lamina. The increase in nonreducing and total sugars in intercoastal lamina due to $\mathrm{K}$ deficiency was overcome upon supplying $\mathrm{Na}$ to K-deficient plants. The effect of $\mathrm{K}$ deficiency on the midribs was only apparent as an increase in nonreducing sugars. When K-deficient plants were supplied $\mathrm{Na}$ to the extent $\mathrm{K}$ was deficient, the nonreducing sugars were decreased significantly to a concentration that was not only lower than K-deficient plants but also lower than normal plants.

Potassium deficiency did not have any marked influence on the starch concentration in the midrib or marginal part of the lamina, but starch concentration in the intercoastal lamina of these leaves was decreased significantly (Table 2). Supplying Na to low-K plants ameliorated the $\mathrm{K}$ deficiency effect on have any significant effect on the reducing starch concentration in intercoastal lamina, but the effect was not large enough to be significant.

Compared with normal plants, the leaves of K-deficient plants had significantly higher concentrations of nonprotein $\mathrm{N}$ in their marginal and intercoastal parts (Table 2). Potassium deficiency only partially (not significantly) increased the concentration of nonprotein $\mathrm{N}$ in the midrib part. Supplying $\mathrm{Na}$ to K-deficient plants ameliorated the Kdeficiency effect on nonprotein (soluble) N. Deficiency of $\mathrm{K}$ caused a marked and significant decrease in protein and total $\mathrm{N}$ in marginal and intercoastal lamina. When plants were supplied $\mathrm{Na}$ to the extent $\mathrm{K}$ was deficient, the protein (and total) $\mathrm{N}$ showed an increase that was not only significantly higher than in leaves of K-deficient plants but also higher than in normal plants. Unlike lamina, the midrib had a higher concentration of protein in K-deficient than in K-sufficient plants. Supplying $\mathrm{Na}$ to K-deficient plants failed to reverse this effect.

Observed changes in carbohydrates and nitrogenous constituents such as increases in sugars and nonprotein $\mathrm{N}$ and decreases in starch and protein $\mathrm{N}$ in leaves of cauliflower subjected to $\mathrm{K}$ deficiency are in accord with earlier findings (Basha et al., 1980; Bodnyuk et al., 1971; Evans and Sorger, 1966; Fabian-Galan 1970; Forshey and Waynemckee, 1970; Helal and Mengel, 1968; Koch and Mengel, 1970; Loetsch, 1971; Nowakowski, 1971; Okamato, 1967; Ratner and Yeliseova, 1968). This study indicates that the addition of $\mathrm{Na}$ in the culture medium can compensate for K-deficiency effect on sugars, starch, and $\mathrm{N}$ fractions in leaves. These results suggest a beneficial effect of $\mathrm{Na}$ in overcoming the detrimental effect of $\mathrm{K}$ deficiency on carbohydrate and $\mathrm{N}$ metabolism. A similar response to sodium is also known to occur in Italian ryegrass (Lolium multiflorum Lam.), wherein Na partially substitutes for $\mathrm{K}$ in its effects on soluble carbohydrates and $\mathrm{N}$ fractions (Nowakowski, 1971; Nowakowski et al., 1974) under conditions of severe K deficiency. Studies on distribution of various carbohydrate and $\mathrm{N}$ fractions in various regions of leaves showed that the intercoastal lamina was most responsive to sodium, possibly because this part, which is the major assimilatory area of the leaf, shows most marked increase in $\mathrm{K}$ concentration when low-K plants are supplied with $\mathrm{Na}$.

These studies reveal a beneficial effect of $\mathrm{Na}$ in preventing increased accumulation of low molecular weight carbohydrate and nitrogenous compounds that predispose low-K plants to parasitic attack and reduce crop quality (Perrenoud, 1977).

\section{Literature Cited}

Basha, S.K., Mahaboob, and G. Rajeshwara Rao. 1980. Effect of potassium deficiency on growth and metabolism of peanut (Arachis hypogaea cultivar TMV-2) plants. Proc. Ind. Acad. Sci. (Plant Sci.) 89:415-420.

Bodnyuk, A.G., G.V. Ustimenko, and A.M. Siniyukhin. 1971. The effect of potassium on physiological processes during tuber formation 
in Ipomoea batatas. Izu. Akad. Nauk. Sssr. Ser. Biol. 1:114-121.

Chibnall, A.C., M.W. Raes, and E.P. Williams. 1943. The total nitrogen content of albumin and other protein. Biochem. J. 37:354-359.

Evans, H.J. and G.J. Sorger. 1966. Role of mineral elements with emphasis on the univalent cations. Annu. Rev. Plant Physiol. 17:47-76.

Fabian-Galan, G. 1970. Influence of phosphorus and potassium deficiency on the free amino acids content of sunflower leaves. Rev. Roum. Biol. Ser. Bot. 15:345-349.

Forshey, C.G. and M. Waynemckee. 1970. Effect of potassium deficiency on nitrogen metabolism of fruit plants. J. Amer. Soc. Hort. Sci. 95:727729.

Helal, M. and K. Mengel. 1968. Der Einfluss einer variierten $\mathrm{N}$-und $\mathrm{K}$-Ernährung auf den $\mathrm{Ge}$ halt and löslichen Aminoverbindungen und auf die Ertragsbildung bei Sommer-weizen. Z Pflanzenernaehr Bodenkd. 120:89-98.

Hewitt, E.J. 1966. Sand and water culture meth- ods used in the study of plant nutrition. 2nd ed. Common. Agr. Bur., England.

Koch, K. and K. Mengel. 1970. The effect of a varied $\mathrm{N}$ and $\mathrm{K}$ supply on the content of soluble amino acids and on the yield of sugarbeets. Landwirt. Forsch. 23:353-362.

Loetsch, B. 1971. Succulence and potassium accumulation of nitrogen deficient plants. Z. Pflanzenphysiol. 65:393-399.

Mengel, K. and M. Helal. 1968. Der Einfluss einer variierten $\mathrm{N}$-und $\mathrm{K}$-Ernährung auf den $\mathrm{Ge}-$ halt an löslichen Aminoverbindungen in der Oberirdischen Pflanzenmass von Hafer. Z. Pflanzenernaehr. Bodenkd. 120:12-20.

MontGomery, R. 1957. Determination of glycogen. Arch. Biochem. Biophys. 67:378-386.

Nelson, N. 1944. Photometric adaptation of Somogyi's method for determination of glucose. J. Biol. Chem. 153:375.

Nowakowski, T.Z. 1971. Effects of potassium and sodium on the contents of soluble carbohydrates and nitrogenous compounds in grass. Potassium in biochemistry and physiology. 8th Colloq. Intl. Potash Inst., Berne, Switzerland. p. 45-49.

Nowakowski, T.Z., J. Bolton, and M. Byers. 1974. Effect of replacing potassium by sodium on growth and on inorganic and organic composition of Italian ryegrass. J. Sci. Food Agr. 25:271283.

Okamato, S. 1967. Effects of potassium nutrition on the glycolysis and the Krebs cycle in taro plants. Soil Sci. Plant Nutr. 13:143-150.

Perrenoud, S. 1977. Potassium and plant-health. Potash Inst., Bern, Switzerland.

Piper, C.S. 1942. Soil and plant analysis. The University, Adelaide, Australia.

Ratner, E.I. and O.I. Yeliseova. 1968. Effect of source of potassium assimilated by plants on metabolism of nitrogenous substances in leaves in connection with organic acid metabolism. Fiziol. Rastenij. 15:488-497.

Sharma, C.P. and S. Singh. 1990. Sodium helps overcome potassium deficiency effects on water relations of cauliflower. HortScience 25:458459 . 